\title{
Microbiomes and Pathogen Survival in Crop Residues, an Ecotone Between Plant and Soil
}

\author{
Lydie Kerdraon, Valérie Laval, and Frédéric Suffert ${ }^{\dagger}$ \\ UMR BIOGER, INRA, AgroParisTech, Université Paris-Saclay, 78850 Thiverval-Grignon, France
}

Accepted for publication 7 August 2019.

\begin{tabular}{|c|c|}
\hline $\begin{array}{l}\text { The negative contribution of crop residues as a source of } \\
\text { inoculum for plant diseases is well established. However, } \\
\text { microbial ecologists have long reported positive effects of } \\
\text { residues on the stability of agrosystems and conservation } \\
\text { tillage practices have become increasingly widespread. Most } \\
\text { studies have suggested that large microbial communities } \\
\text { should be taken into account in plant disease management, } \\
\text { but we know little about their ecological interaction with pathogens } \\
\text { in the crop residue compartment. This review focuses on } \\
\text { microbiomes associated with residues within the context of } \\
\text { other microbial habitats in cereal-producing agroecosystems } \\
\text { such as phyllosphere or rhizosphere. We connected residue } \\
\text { microbiome with the survival of residue-borne fungal plant } \\
\text { pathogens, thus combining knowledge in microbial ecology and } \\
\text { epidemiology, two disciplines still not sufficiently connected. } \\
\text { We provide an overview of the impact of residues on cereal } \\
\text { disease enidemics and how dynamic interactions between }\end{array}$ & $\begin{array}{l}\text { next-generation microbiome-based biocontrol strategies. Starting } \\
\text { from the classical but still relevant view of crop residues as a } \\
\text { source of pathogen inoculum, we first consider possibilities for } \\
\text { limiting the amount of residues on the soil surface to reduce } \\
\text { the pathogen pressure. We then describe residues as a transient } \\
\text { half-plant/half-soil compartment constituting a key fully fledged } \\
\text { microbial ecosystem: in other words, an ecotone which deserves } \\
\text { special attention. We focus on microbial communities, the changes } \\
\text { in these communities over time and the factors influencing them. } \\
\text { Finally, we discuss how the interactions between the microbial } \\
\text { communities and the pathogens present on residues could be } \\
\text { used: identification of keystone taxa and beneficial assemblages, } \\
\text { then preservation of these taxa by adapted agronomic practices or } \\
\text { development of synthetic communities, rather than the introduction } \\
\text { of a single exogenous biocontrol species designed as a treatment } \\
\text { product. }\end{array}$ \\
\hline $\begin{array}{l}\text { microbial communities of nonburied residues during their } \\
\text { degradation, along with soil and multitude of abiotic factors, can } \\
\text { contribute to innovative disease management strategies, including }\end{array}$ & $\begin{array}{l}\text { Keywords: agroecology, crop residues, fungal plant pathogen, } \\
\text { microbiome, microbiota, microbial communities, plant disease } \\
\text { epidemiology, primary inoculum, rhizosphere and phyllosphere }\end{array}$ \\
\hline
\end{tabular}

Crop residues, i.e., the decaying parts of the crop plant that is not harvested, are sometimes considered waste. However, they are actually a source of essential environmental services necessary for the perpetuation of productive agrosystems (Smil 1999). The conservation of crop residues in the field after harvest with reduced-

${ }^{\dagger}$ Corresponding author: F. Suffert; frederic.suffert@inra.fr

Funding: This review was supported by a 2015-2019 grant from the European Union Horizon Framework 2020 Program (Grant Agreement no. 634179, EMPHASIS project) and a 2014-2016 grant overseen by the French National Research Agency (ANR) as part of the "Investissements d'Avenir" programme (LabEx BASC; ANR11-LABX-0034; API-SMAL flagship project).

*The $e$-Xtra logo stands for "electronic extra" and indicates that one supplementary figure is published online.

The author(s) declare no conflict of interest. or no-tillage practices allow the formation of soil organic carbon, improve soil structure, prevent erosion, filter and retain water, and reduce evaporation by maintaining a substantial part of crop residues on the soil surface (Derpsch et al. 2010; Govaerts et al. 2007). Yet, these practices, which are becoming increasingly common worldwide (Awada et al. 2014; de Freitas and Landers 2014; Kertész and Madarász 2014), increase the risk of "residue-borne" or "stubble-borne" disease epidemics, due to the presence of crop residues acting as a source of primary inoculum (Bailey 1996; Bailey and Lazarovits 2003; Bockus and Shroyer 1998). Indeed, several leaf-, stem-, and head-infecting microorganisms are known to survive on crop residues between cropping seasons (Bockus and Shroyer 1998; Cook et al. 1978). Residue conservation tends to increase the risk of epidemics for many foliar diseases, especially on cereals (Bailey 1996; Bailey and Lazarovits 2003; Bockus and Shroyer 1998). For instance, wheat pathogens, such as Pyrenophora tritici repentis (Adee and Pfender 1989), Oculimacula yallundae (Vera and Murray 2016), and Zymoseptoria tritici (Suffert and Sache 2011), have been shown to be more likely to 
infect the subsequent crop if wheat residues are left in the field after harvest. The survival of such pathogens usually results from the formation of fruiting bodies arising from sexual reproduction on crop residues. These fruiting bodies, once mature, release spores for several months or even years, which can be spread over long distances and thus contaminate subsequent crops. The current review is focused on wheat residues, as cereal pathogens are agronomically important and well documented in the literature, but the ideas could be applicable to other crop/pathogen associations.

Epidemiological considerations have expanded to include new microbial ecological concepts, such as the "pathobiome", defined as the pathogen and the cohort of associated microorganisms likely to influence the persistence, transmission, and evolution of the pathogen (Vayssier-Taussat et al. 2014). This concept encompasses the "microbiota", defined as the assemblage of microorganisms present in a given environment, whereas the "microbiome" is defined as the entire habitat, including the microorganisms, their genomes, and the surrounding environmental conditions (Marchesi and Ravel 2015) as a distinct additional node influenced by the three components of the classic epidemiological triangle (Supplementary Fig. S1) (Foxman and Rosenthal 2013; Hanson and Weinstock 2016; Legrand et al. 2017; Paulitz and Matta 1999). The "pathogen" is finally repositioned into a broader community context. It is considered as one of many taxa responsible for disease that interacts positively or negatively with other taxa present in the same ecological niche. Disease expression seems to be the result of an imbalance between a potentially pathogenic species and the rest of the microbial community on host tissues, rather than simply a consequence of just the presence of the pathogenic species (Vayssier-Taussat et al. 2014). The categorization of a species is rendered more complex by the fact that microorganisms reported to act as crop pathogens or endophytes can also develop without symptom development, or as saprotrophs in the soil and plant residues. Microbial assemblages harbor "keystone taxa" (Banerjee et al. 2018), which exert individually or in a guild, i.e., group of species that exploit the same resources, a considerable influence on microbiome structure and can drive community composition and function irrespective of their abundance across space and time. Thus, agronomic practices can theoretically cause a dramatic shift in microbiome structure and functioning by removing these keystone taxa, but can also reduce pathogen propagation and plant infection by beneficial microorganisms. The key questions are as follows. Which microorganisms should be considered beneficial? Are these beneficial microorganisms keystone taxa within the community? Which management practices could preserve or promote these keystone taxa and enhance their positive activity against residue-borne diseases?

A large number of studies focused on plant and soil microbiomes, but the microbial communities specific to the crop residues left on the soil surface have been little investigated. The few studies concerning crop residues conducted to date have focused on the impact of buried residues on soil microbial communities, rather than on the residue microbial communities. In addition, they were performed in microcosms, with sterilized residues (Bastian et al. 2009; Cookson et al. 1998; Nicolardot et al. 2007). Such study conditions are not optimal because they greatly decrease the complexity of the residue microbiome.

This thought-provoking review situates the microbiome associated with crop residues within the context of other microbial habitats in cereal-producing agroecosystems. We start from the classical but still relevant view of crop residues as a source of pathogen inoculum, highlighting the limits of their quantitative management. We then go on to better define crop residues as an ecological "compartment" that has strong spatial and temporal relationships with plant and soil compartments, firstly based on a "static" representation, and then on more dynamic processes and interactions. We pass from the notion of substrate to pathobiome by focusing on the microbial communities present on residues, changes in these communities over time, and the factors likely to influence them. Finally, we reflect on the possible uses of the communities present on the residues and possible interactions with pathogens. We considered the possibility of identifying potential biocontrol agents from the cultivable part of these communities by microbiome-based strategies.

\section{IMPACT OF CROP RESIDUES ON THE DEVELOPMENT OF FUNGAL DISEASE EPIDEMICS: CEREAL CROPPING SYSTEMS AS CASE STUDY}

Tillage, defined as the mechanical manipulation of soil and plant residues for seedbed preparation (Reicosky and Allmaras 2003), has been associated with agriculture for several millennia. Deep tillage systems has several benefits, including weed control, greater yields and root length densities for some crop species (Varsa et al. 1997), but tillage also has negative consequences on the soil: disruption of structure, erosion (Borrelli et al. 2017), and reduction in organic carbon depending on factors such as depth of measurement, soil type, and tillage method (Haddaway et al. 2016). No-tillage has repeatedly been shown to have beneficial effects on soil preservation. The retention of crop residues at the soil surface prevents water erosion, by reducing the direct impact of raindrops (Chambers et al. 2000; Hobbs 2007), reducing runoff velocity and giving water longer to infiltrate (Pimentel et al. 1995). It also prevents wind erosion by protecting the soil and enhancing the soil's physical, chemical, and biological properties (Kassam et al. 2015; Verhulst et al. 2010). No-tillage has another positive impact, by decreasing the emissions from farming activities through the reduction of mechanical operations (Govaerts et al. 2007) and from carbon sequestration (Govaerts et al. 2009). Finally, Conservation Agriculture and no-tillage practices, and the use of permanent soil cover and rotations (Hobbs 2007) have steadily increased from 2.8 million ha in $1973 / 1974$ to 106 million ha in 2008/ 2009 and to more than 180 million ha in 2015/2016 in the world (Derpsch et al. 2010; Kassam et al. 2019).

The retention of residues at the soil surface can also have a negative effect: the promotion of so-called "residue-borne" diseases. These crop diseases, many of which are foliar, are mainly caused by fungal pathogens that can overwinter on residues by carrying out a specific part of their life cycles leading to the production of primary inoculum (Dyer et al. 1996; Leplat et al. 2013; Shaw and Royle 1989; Suffert and Sache 2011; Vera and Murray 2016). Unburied crop residues lying on the soil surface in lowtillage systems can be seen as a "brown bridge" of dead plant material that can harbor multiple pathogenic, saprotrophic or endophytic species (Thompson et al. 2015). Crop residue management is a particularly important issue as residues can have a major impact as a recurrent source of inoculum over long periods, often exceeding the interepidemic period during the intercropping season when host plants are not present in the agrosystem. For instance, spores of Fusarium species, a pathogen of cereals such as wheat and maize, could be released for up to 3 years after harvest from maize residues (Pereyra et al. 2004).

The survival of plant pathogens on crop residues was shown to be inversely correlated with the amount of residues buried or exported after harvest (Bockus and Claassen 1992; Carignano et al. 2008; DillMacky and Jones 2000; Guo et al. 2005; Jørgensen and Olsen 2007) and with the degree of residue degradation (Gosende et al. 2003; Hershman and Perkins 1995; Leplat et al. 2013; Marcroft et al. 2003; Pereyra and Dill-Macky 2008; Pereyra et al. 2004; Summerell and Burgess 1989). However, it is difficult to generalize the quantitative 
impact of residues as an effective source of inoculum (Morais et al. 2016), because the nature of the survival structures depends on the biology of the pathogen and the environmental conditions.

Most disease management strategies target the epidemic period of the disease, although interepidemic period is crucial for pathogen survival, as highlighted above. Decreasing the presence of a pathogen during the interepidemic period could theoretically limit disease development in the next crop and even over the next few years. A correlation between the amount of primary inoculum at the end of the growing season and disease severity during the next season has been established for Leptosphaeria maculans pathogen of oilseed rape (Lô-Pelzer et al. 2009) and Pyrenophora tritici repentis (Adee and Pfender 1989; Bockus and Claassen 1992), Stagonospora nodorum (Mehra et al. 2015), and Zymoseptoria tritici (Suffert et al. 2018) pathogens of wheat.

A number of studies have demonstrated the value of managing the primary inoculum to limit disease severity during the epidemic period (Adee and Pfender 1989; Filho et al. 2016), but in several cases the amount of primary inoculum is not a limiting factor for the development of epidemics (Alabouvette et al. 2006). This is the case, for example, for polycyclic diseases caused by pathogens capable of multiple infection cycles with inoculum increases throughout the growing season (Burdon and Laine 2019).

\section{CROP RESIDUES, A SHIFTING COMPARTMENT HOSTING MICROBIAL COMMUNITIES INTERACTING WITH PLANT AND SOIL}

The residues, ecotone in the interface between the plant and soil: Definitions and concepts. Buried and nonburied crop residues should be distinguished according to their location: above- and below-ground, respectively (Fig. 1). This distinction makes perfect sense in terms of the epidemiology of plant diseases, as buried residues are no longer a source of inoculum for airborne diseases as highlighted above. The term "residue sphere" identifies the microhabitat consisting of all crop residues, whether buried or nonburied. However, this term has occasionally been used as a synonym of "detritusphere" (Magid et al. 2006; Sengeløv et al. 2000), which is defined as the soil adjacent to plant residues (Marschner et al. 2011; Pascault et al. 2010a; Poll et al. 2008). The detritusphere is considered to be the part of the soil immediately affected by residue degradation, and is generally assumed to include

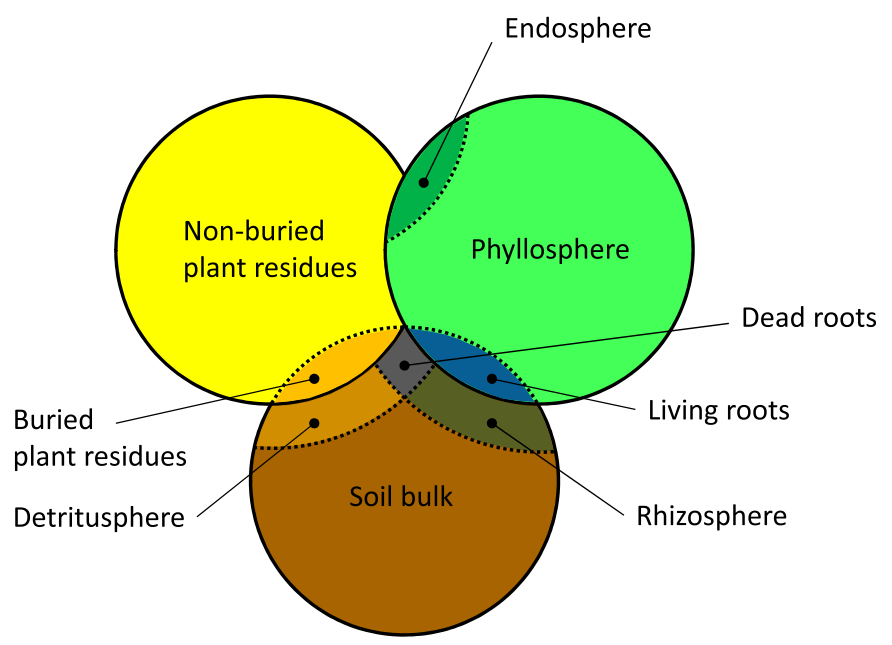

Fig. 1. Positioning of the crop residues in relation to the other compartments constituting the different ecological niches of an agrosystem. the first $6 \mathrm{~mm}$ (Bastian et al. 2009; Nicolardot et al. 2007) or $10 \mathrm{~mm}$ (Magid et al. 2006) of soil surrounding the residues at all times in stratified experiments. This top layer of the soil is very thin but has high levels of microbial activity (Kuzyakov and Blagodatskaya 2015). The detritusphere has been also defined ambiguously by some authors as the layer of soil including the litter and the adjacent soil influenced by the litter (Gaillard et al. 1999; Ingwersen et al. 2008). An experimental comparison of the various soil zones (residues, detritusphere, and bulk soil) indicated that the bacterial and fungal communities are specific to a residue type in the detritusphere and to the location of residues (Nicolardot et al. 2007). Residue degradation has been shown to induce a particular genetic structure of the microbial community with a gradient from residue to bulk soil. Based on these findings, it was concluded that the residues, detritusphere, and bulk soil corresponded to different trophic and functional niches for microorganisms.

Residues should be considered as a distinct microbial substrate (Bastian et al. 2009), characterized by the plant from which they originate, and by their degradation stage, implying chemical and physical changes dependent on their position relative to the soil surface. Residues originate from the plant (temporal link), are in close contact with the soil (spatial link) and decay over the following cropping season, at rates dependent on plant species, cropping practices (Hadas et al. 2004), and year (climate effect). Residues are definitely not a specific "static" compartment and should be viewed as "transient" (Fig. 2).

Microbial communities of residues are inherited from the plant. The plant hosting the "phytobiome", which consists of the plant communities of organisms - micro- and macro-organisms - present in and on plants, includes the phyllosphere, rhizosphere and endophytic compartments (Fig. 1). These three compartments make a crucial contribution to the crop residues. Microorganisms are adapted to particular ecological niches and physiological conditions (Grudzinska-Sterno et al. 2016; Larran et al. 2007; Vorholt 2012) and are driven by numerous biotic and abiotic factors (e.g., temperature, humidity, and light) (Carvalho and Castillo 2018), including the plant itself, whether considered at the species or genotype level (Bodenhausen et al. 2014; Wagner et al. 2016). The effect of the plant is therefore mainly due to two aspects: (i) it is already colonized by microorganisms that can remain on the residues (e.g., hemibiotrophic pathogens) and (ii) it has different biochemical compositions, which can affect the rate of degradation and the changes in the chemical and physical properties of the residues. These two aspects are closely linked, because the microorganisms present on plants are partly dependent on the biochemistry of the plant (species, genotype) and because these microorganisms can have a reciprocal impact on the plant properties, even before any degradation has occurred (changes in $\mathrm{C} / \mathrm{N}$ ratio, production of defense compounds by plants in response to colonization by microorganisms, etc.). Both aspects must be taken into account when trying to understand how new microorganisms colonize residues and how their microbiota changes over time in the agrosystem.

Green tissues of plants are naturally infected with endophytic species. Biocontrol engineering practices based on artificial inoculation with such endophytic species are not yet largely used with exogenous fungal or bacterial strains during a cropping season, probably because of the complexity of the microbial interactions involved and their alteration by variations in agro-environmental conditions in field conditions (De Silva et al. 2019). Nevertheless, it is established that endophytic species naturally present in cultivated plants can limit the development of pathogens during the cropping season (Stone et al. 2018). It is therefore likely that their action would continue on the residues during the intercropping season. 


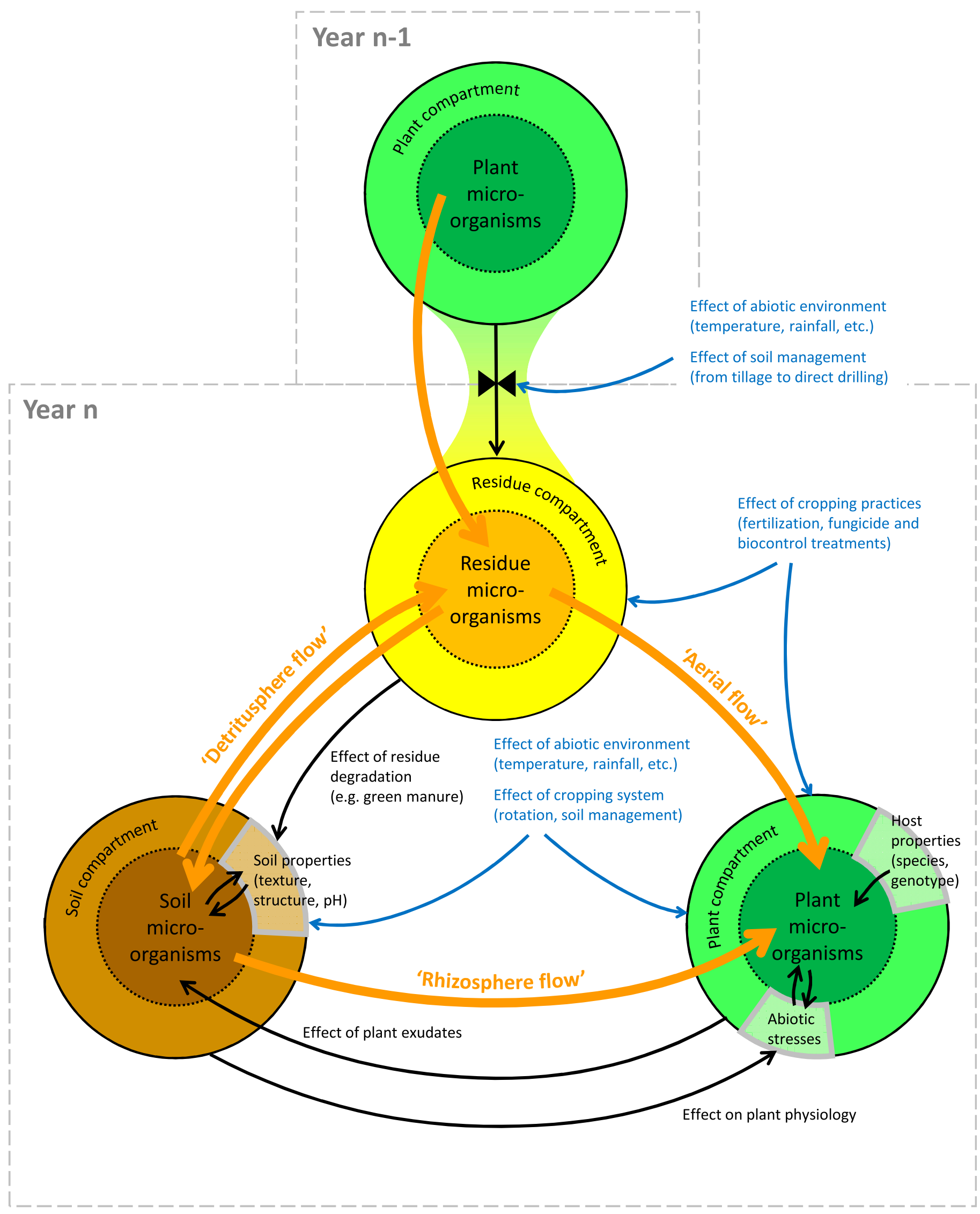

Fig. 2. Representation of the most significant dynamic relationships-flow of microorganisms (orange arrows), biotic interactions (black arrows), and abiotic or cropping effects (blue arrows) — between the crop residue, plant, and soil compartments in an agrosystem. 
The microbial communities present on the residues at the beginning of their degradation depend on the plant (species, genotype, and organ) and on a pool of other organisms that differ according to the events in the plant's life and the environment in which it was grown (biotic and abiotic stresses). Even after the residues come into contact with the soil, the influence of the plant species on residue colonization is evident (Kerdraon et al. 2019a; Nicolardot et al. 2007). Plant genotype also determines the structure of the microbial communities of the whole phyllosphere, particularly in cases of resistance to certain pathogens, but also for epiphytes and endophytes in the case of wheat (Karlsson et al. 2017; Sapkota et al. 2015). Comby et al. (2017) showed that the temporal variation of wheat microbial communities in natural conditions was driven by a succession of plant pathogens. The communities present on plants also depend on the organ considered. This is particularly true for aerial organs and roots, because of the differences between habitats in terms of nutrients and exposure (Comby et al. 2016). However, several species, such as Cladosporium sp. and Microdochium nivale, can colonize all parts of the plant (Gdanetz and Trail 2017; Grudzinska-Sterno et al. 2016). Moreover, the age of each organ has been shown to determine the communities present (Wagner et al. 2016). In some cases, the proportion of pathogenic fungi increases with plant development (Grudzinska-Sterno et al. 2016). Crop rotation does not appear to affect the communities associated with leaves, but does seem to affect root-associated communities, as demonstrated in a wheat-pea rotation (Granzow et al. 2017). It can be concluded from these various examples that pathogenic and nonpathogenic microorganisms present on plants remain on the residues and influence the subsequent dynamics of colonization by other microorganisms.

Microbial abundance and composition of the phyllosphere changes over time, which drives colonization of residues by specific microorganisms over the cropping season (Peñuelas et al. 2012). The biochemical composition of crop residues, which depends on the plant species from which they are derived, is one of the factors determining the structure and diversity of bacterial communities (Baumann et al. 2009; Pascault et al. 2010b). Residue degradation has been shown to depend on the complex chemical composition of the residues, taking into account the $\mathrm{C} / \mathrm{N}$ ratio, and the nitrogen and lignin contents of the plant (Kriaučiuniene et al. 2012). The colonizing microbial communities differ between plant species, on identical soils. This has been established, for example, by comparing the degradation dynamic of different crop residues (soybean, corn, wheat, oilseed rape, and alfalfa) (Broder and Wagner 1988; Pascault et al. 2010a). Differences between "recalcitrant" and "easily degradable" residues that underwent faster changes were related to differences in the microbial communities present: those rich in organic substrates consisted mostly of copiotrophic genera, whereas those from an environment poor in organic substrates consisted mostly of oligotrophic genera. Furthermore, fungi are considered the main decomposers of recalcitrant compounds, whereas bacteria break down simple substrates (de Boer et al. 2005).

The gradual degradation of crop residues induce changes over time in the structure of microbial communities, and these microbial communities have a reciprocal effect, inducing biochemical transformations in the crop residues hosting them. A change in the bacterial and fungal communities present on wheat residues has been observed between the early stages of degradation (14 and 56 days after the incorporation of residues into the soil) and later stages (56 to 168 days) (Bastian et al. 2009). This change was interpreted as a modification in the balance between copiotrophic and oligotrophic organisms. Residue communities are also influenced by cultivation techniques: residues are degraded differently in aerobic and anaerobic conditions (Cookson et al. 1998). This results in different mobilized communities, including different bacterial and fungal cellulolytic species (de Boer et al. 2005), as degradation processes are not the same (Nicolardot et al. 2007). The functional composition of the microbial communities (cellulolytic versus lignolytic) depends on the physicochemical properties of the soil, such as $\mathrm{pH}$.

Impact of the soil on changes in the microbial communities of nonburied residues during their degradation. Separating the "plant inheritance" effects from the "soil" effects is difficult, especially when considering degradation processes. It is easier for species whose origin can be determined with certainty because of specificities of their life cycle. For example, certain strictly biotrophic fungi such as rusts (Puccinia) or mildew (Erysiphe) are typically found in the phyllosphere, whereas strictly telluric bacteria or arbuscular mycorrhizal fungi will be observed in the bulk soil. The addition of crop residues to soil results in considerable heterogeneity in soil microbial community diversity, where three distinct zones have been identified: (i) the residues themselves, (ii) the detritusphere (the soil zone in close contact with the residues), and (iii) the bulk soil (the distant soil zone unaffected by residue decomposition) (Nicolardot et al. 2007). The greatest microbial diversity dynamics was observed on the residues, suggesting that the distinction between these compartments should be not only "static" (Fig. 1) but also "dynamic" as microbial interactions change over the residue degradation (Fig. 2) (Nicolardot et al. 2007).

There are still significant gaps in our knowledge of functional ecology and diversity of microbial communities present on nonburied residues and their interaction with bulk soil. The residue mulch is suspected to be mainly decomposed by the fungal communities since soil under no tillage contains greater proportions of fungi to bacteria than those under conventional tillage, while bacteria are generally considered to be the predominant decomposers of incorporated crop residues under conventional tillage (Anderson et al. 2017; Hellequin et al. 2018; Navarro-Noya et al. 2013). Some studies performed under controlled laboratory conditions help characterize the impact of crop residue inputs on the diversity of soil microbial communities (Bastian et al. 2009; Nicolardot et al. 2007), but the converse relationship has been rarely investigated. Finally, it is difficult to know whether the results of such studies, beyond the methodological aspects (e.g., metabarcoding), can be extrapolated to understand the impact of bulk soil on changes in microbial communities hosted by residues during their degradation.

Evidence for a major impact of soil compartment on the dynamics of microbial communities can only be indirect, such as the comparison of communities, and partial by characterization of ecological functions. For instance, the importance of soil microorganisms in the mineralization of plant residues is well established (Shahbaz et al. 2017; Wardle et al. 2004), but the microbial colonization of residues left on the surface, for example in autumn, 3 to 4 months after harvest when the production of pathogen spores released from residues of infected wheat peaks, is not well documented.

The degree of contact between crop residues and the bulk soil, which is determined by the amount of residues left on the soil surface and the intensity of incorporation in the soil, affects degradation dynamics under both natural and experimental conditions (Henriksen and Breland 2002). Concretely, poor residue-soil contact reduces the decomposition of structural plant constituents by delaying colonization with microorganisms degrading cellulose and hemicellulose. Several studies focused on the effect of the location of residues (incorporated versus left on the soil surface) and of organic matter on their subsequent degradation, both in large-scale 
field experiments (Guo et al. 2016; Hartman et al. 2018; Pascault et al. 2010a; 2013; Tardy et al. 2015; Xia et al. 2019) and controlled conditions experiments (Bastian et al. 2009; Nicolardot et al. 2007). The aforementioned studies investigated the effect of different management options of residues on soil microbial communities, but very few have looked at the interactions between residue-borne pathogens and the microbiota driving residue degradation. This gap need to be addressed in the future. The ecological richness of the residue compartment at the interface between the plant and soil communities suggests potentially interesting prospects for nextgeneration biocontrol strategies. Indeed, residues can be considered both a source and a target for biological control: a source, because the probability to identify interacting pathogen and beneficial species is higher than in the plant or soil compartment; and a target, because the residues bearing plant pathogens could be treated in order to limit the amount of primary inoculum for several important diseases.

\section{RESIDUE MICROBIOTA AND THE INTERFACE BETWEEN THE PLANT AND SOIL COMMUNITIES: PROSPECTS FOR MICROBIOME-BASED BIOCONTROL SOLUTIONS}

This review highlights that crop residues are transient half-plant/ half-soil compartment, which constitute a key fully fledged microbial ecosystem. This residue microbial system represents an ecotone, as a boundary compartment between two biomes, the plant and the soil. The residue microbiota should be taken into account in the management of residue-borne diseases. It may be possible to identify guilds of beneficial microorganisms naturally present on residues, which could then be preserved, or even selected, characterized and used as biological control agents against the pathogens that complete their life cycle on residues.

Certain residue-borne fungal diseases, such as spot blotch and common root rot on wheat and barley caused by Cochliobolus sativus (Bailey and Lazarovits 2003), tan spot on wheat caused by Pyrenophora tritici-repentis (Bockus 1998; Bockus and Claassen 1992), and blackleg on canola caused by Leptosphaeria maculans (Guo et al. 2005) can be reduced by decreasing the amount of residues on the soil surface. For most other polycyclic plant diseases caused by residue-borne pathogens, the management of crop residues at the field scale may be ineffective for significantly reducing the final disease severity and yield losses in a sustained manner. Such a decrease in pathogen load could only be achieved by limiting the primary inoculum over a larger scale, i.e., in all the fields located at a distance less than the approximate dispersal capacity of this inoculum. This would require combining knowledge of the rate at which spores of pathogens strongly decline with distance from inoculum sources. This review suggests that another complementary approach based on biocontrol strategy exploiting residue microbiota should be considered.

There are currently no examples or studies supporting the strategy of exploiting residue microbiota as biocontrol agents that have led to efficient and practical solutions applied in cereal cropping systems at a large scale. However, plant microbiomes have recently been suggested as the key to future targeted and predictive biocontrol approaches (Berg et al. 2017). For instance, some microorganisms commonly present in the phyllosphere (Paecilomyces lilacinus, Fusarium moniliforme var. anthophilum, Epicoccum nigrum, Bacillus sp., Cryptococcus sp., and Nigrospora sphaerica) have been shown to affect the germination of $Z$. tritici spores (Perello et al. 2002). Some members of the microbial community may also have an impact on plant resistance to certain diseases (Ritpitakphong et al. 2016). A number of effects can be targeted on residues, including increasing the rate of residue degradation by cellulose- or lignin-degrading microorganisms (Dinis et al. 2009), shortening indirectly the survival of certain microorganisms and promoting interactions affecting the saprotrophic development of pathogens, and thus the limitation of primary inoculum production. Some studies have reported beneficial effects of cropping practices, such as decreases in Fusarium graminearum survival due to an increase in the population of microbial soil antagonists induced by the addition of green manure to the soil (Bailey and Lazarovits 2003; Perez et al. 2008; Wiggins 2003; Zhang et al. 2017). A recent study combining metabarcoding and co-occurrence network analysis profiled microbial communities presents in maize residues and their potential interactions with the different pathogenic Fusarium species (Cobo-Díaz et al. 2019). The microbial communities present in the maize residues may represent important taxa that could lead to biocontrol strategies against Fusarium head blight.

Given the high diversity of microorganisms on residues, various modes of action could be used to increase biocontrol efficiency (Alabouvette et al. 2006; Guetsky et al. 2001). Diverse modes of action were described for various microorganisms present on the residues. To our knowledge, only one study has reported biocontrol tests performed on crop residues (chickpea) infected with a residue-borne pathogen (Didymella rabiei). For example, Aureobasidium pullulans can grow faster than D. rabiei, thereby limiting its propagation by competition; and Clonostachys rosea, which has mycoparasitic capacity, can decrease or even totally abolish the sexual and asexual reproduction of D. rabiei (Dugan et al. 2005). Microsphaeropsis sp., which is also known to have mycoparasitic capacity (Benyagoub et al. 1998), has been shown to affect the production of Fusarium graminearum spores on wheat and maize residues (Bujold et al. 2001; Legrand et al. 2017). Bastian et al. (2009) highlighted the colonization of sterile residues deposited back on the soil by bacteria such as Pseudomonas fuorescens, Pseudomonas aurantiaca, and Pseudomonas putida and fungi such as Chaetomium globosum, which have been described as potential biocontrol agents (Clarkson and Lucas 1993; Cordero et al. 2014; Flaishman et al. 1996; Kildea et al. 2008; Larran et al. 2016; Perello et al. 2002; Pfender et al. 1993; Ramarathnam and Dilantha Fernando 2006).

Macroinvertebrates can also have an impact on the residue microbiome. Some empirical studies demonstrated that earthworms (e.g., Lumbricus terrestris) (Wolfarth et al. 2011) can reduce the Fusarium culmorum biomass and deoxynivalenol concentration in wheat straw left on the soil surface. Among detritivorous species, collembolans (e.g., Folsomia candida) and nematodes (e.g., Aphelenchoides saprophilus) also take an important role in the control of phytopathogenic and toxinogenic fungi surviving on crop residues (Wolfarth et al. 2013, 2016): these organisms can be viewed as potential drivers to compensate negative consequences of conservation tillage.

\section{PERSPECTIVES}

Would it be possible to reduce the presence and activity of a pathogen in the microbial community of crop residues, through interactions with other species: competition for resources, antagonism, or parasitism? If this is, indeed, possible, it would not be performed by classical biocontrol consisting of the introduction of an exogenous microorganism, as such approaches have not always translated well under field conditions. The limitation of pathogen impact would be probably through the exploitation of functional, agro-ecological relationships to identify a guild of microorganisms consisting of one or several keystone taxa that compose the 
"beneficial fraction" of the community and then to promote these microorganisms. The challenge concerns both the identification of the microorganisms and their promotion, but to make advances, the factors favoring microorganisms must also be identified. This issue is a huge bottleneck to success and should be of growing importance for both academic and operational research working toward the development of microbiome-based biocontrol solutions. An accurate descriptive approach and the characterization of interactions within the residue microbiota are required. Next-generation sequencing is a promising technology for this approach (Toju et al. 2018). It provides access to the diversity of nonculturable microorganisms, facilitating the discovery of new species (Lagier et al. 2016) and more detailed community description (Kerdraon et al. 2019a). Co-occurrence network analysis can help to identify potentially important endemic species with biocontrol activity by obtaining a better understanding of ecological processes (Kerdraon et al. 2019b), but a "co-occurrence species" per se does not mean "real activity". Moreover, keystone taxa identified by this way are probably not the only species that may be playing a critical role within a microbial community and the strategy of co-occurrence network analysis could be expanded to characterize the activity of exogeneous species introduced as biocontrol agents and their impact on the whole endogenous community. Some of the next-generation sequencing techniques available could be used to characterize the diversity of the microbial communities associated with the pathogen throughout their life cycle during both the epidemic and interepidemic periods, even if these periods are cryptic. We must be aware that the epidemic period is probably not the only period to target: the objective is not to find a species that can replace a fungicide applied during crop growth, but also to understand how species, from single taxa to more complex microbial assemblage, can reduce the amount of primary inoculum during the interepidemic period. Nonculturable microorganisms clearly cannot be used for biocontrol methods involving the introduction of exogeneous species, but we need to know more about their activity in natural conditions. It would then be possible to test, in vitro or in planta, the culturable species isolated from residues and identified as potential biocontrol agents, based on integrative strategies focusing on plants during their development (Gdanetz and Trail 2017). To date, practical biocontrol solutions were usually based on single beneficial strains. This thought-provoking review suggests that such solutions may be improved by developing microbiome-based strategies based on more complex microbial assemblage such as "synthetic communities", that can reintroduce natural complexity (Herrera Paredes et al. 2018; Sergaki et al. 2018). Tsolakidou et al. (2019) recently proposed that microbial synthetic communities can be used as compost inoculants to produce composts with desired characteristics. The creation of synthetic ecosystems using microbial mixtures can lead to promising solutions for sustainable agricultural practices. In that direction, further study is needed to understand how synthetic communities persevere in crop residues and what are the additive traits of a community compared with single species. Residues considered as an ecotone in the interface between the plant and soil are a compartment particularly rich in microorganisms, which is ideal not only for identifying assemblages of interest but also as pathogen inoculum source being itself the target of biocontrol synthetic communities.

\section{ACKNOWLEDGMENTS}

We thank J. Sappa for her help correcting our English. We also sincerely thank C. Young and the five anonymous reviewers for their insightful comments of the manuscript and their enthusiasm for the subject.

\section{LITERATURE CITED}

Adee, E. A., and Pfender, W. F. 1989. The effect of primary inoculum level of Pyrenophora tritici-repentis on tan spot epidemic development in wheat. Phytopathology 79:873-877.

Alabouvette, C., Olivain, C., and Steinberg, C. 2006. Biological control of plant diseases: The European situation. Eur. J. Plant Pathol. 114: 329-341.

Anderson, C., Beare, M., Buckley, H. L., and Lear, G. 2017. Bacterial and fungal communities respond differently to varying tillage depth in agricultural soils. PeerJ 5:e3930.

Awada, L., Lindwall, C. W., and Sonntag, B. 2014. The development and adoption of conservation tillage systems on the Canadian prairies. Int. Soil Water Conserv. Res. 2:47-65.

Bailey, K., and Lazarovits, G. 2003. Suppressing soil-borne diseases with residue management and organic amendments. Soil Tillage Res. 72: 169-180.

Bailey, K. L. 1996. Diseases under conservation tillage systems. Can. J. Plant Sci. 76:635-639.

Banerjee, S., Schlaeppi, K., Marcel, G. A., and van der Heijden, M. G. A. 2018. Keystone taxa as drivers of microbiome structure and functioning. Nat. Rev. Microbiol. 16:567-576.

Bastian, F., Bouziri, L., Nicolardot, B., and Ranjard, L. 2009. Impact of wheat straw decomposition on successional patterns of soil microbial community structure. Soil Biol. Biochem. 41:262-275.

Baumann, K., Marschner, P., Smernik, R. J., and Baldock, J. A. 2009. Residue chemistry and microbial community structure during decomposition of eucalypt, wheat and vetch residues. Soil Biol. Biochem. 41:1966-1975.

Benyagoub, M., Benhamou, N., and Carisse, O. 1998. Cytochemical investigation of the antagonistic interaction between a Microsphaeropsis sp. (isolate P130A) and Venturia inaequalis. Phytopathology 88:605-613.

Berg, G., Köberl, M., Rybakova, D., Müller, H., Grosch, R., and Smalla, K. 2017. Plant microbial diversity is suggested as the key to future biocontrol and health trends. FEMS Microbiol. Ecol. 93:fix050.

Bockus, W., and Claassen, M. M. 1992. Effects of crop rotation and residue management practices on severity of tan spot of winter wheat. Plant Dis. 76: 633-636.

Bockus, W. W. 1998. Control strategies for stubble-borne pathogens of wheat. Can. J. Plant Pathol. 20:371-375.

Bockus, W. W., and Shroyer, J. P. 1998. The impact of reduced tillage on soilborne plant pathogens. Annu. Rev. Phytopathol. 36:485-500.

Bodenhausen, N., Bortfeld-Miller, M., Ackermann, M., and Vorholt, J. A. 2014. A synthetic community approach reveals plant genotypes affecting the phyllosphere microbiota. PLoS Genet. 10:e1004283.

Borrelli, P., Robinson, D. A., Fleischer, L. R., Lugato, E., Ballabio, C., Alewell, C., Meusburger, K., Modugno, S., Schütt, B., Ferro, V., et al. 2017. An assessment of the global impact of 21st century land use change on soil erosion. Nat. Commun. 8:2013.

Broder, M. W., and Wagner, G. H. 1988. Microbial colonization and decomposition of corn, wheat, and soybean residue. Soil Sci. Soc. Am. J. 52: 112-117.

Bujold, I., Paulitz, T. C., and Carisse, O. 2001. Effect of Microsphaeropsis sp. on the production of perithecia and ascospores of Gibberella zeae. Plant Dis. 85: 977-984.

Burdon, J. J., and Laine, A. L. 2019. Evolutionary Dynamics of Plant-Pathogen Interactions. Cambridge University Press, Cambridge.

Carignano, M., Staggenborg, S. A., and Shroyer, J. P. 2008. Management practices to minimize tan spot in a continuous wheat rotation. Agron. J. 100: 145-153.

Carvalho, S. D., and Castillo, J. A. 2018. Influence of light on plant-phyllosphere interaction. Front. Plant Sci. 9:1482.

Chambers, B. J., Garwood, T. W. D., and Unwin, R. J. 2000. Controlling soil water erosion and phosphorus losses from arable land in England and Wales. J. Environ. Qual. 29:145-150.

Clarkson, J., and Lucas, J. 1993. Screening for potential antagonists of Pseudocercosporella herpotrichoides, the causal agent of eyespot disease of cereals: 1. Bacteria. Plant Pathol. 42:543-551.

Cobo-Díaz, J. F., Baroncelli, R., Le Floch, G., and Picot, A. 2019. Combined metabarcoding and co-occurrence network analysis to profile the bacterial, fungal and Fusarium communities and their interactions in maize stalks. Front. Microbiol. 10:261.

Comby, M., Gacoin, M., Robineau, M., Rabenoelina, F., Ptas, S., Dupont, J., Profizi, C., and Baillieul, F. 2017. Screening of wheat endophytes as 
biological control agents against Fusarium head blight using two different in vitro tests. Microbiol. Res. 202:11-20.

Comby, M., Lacoste, S., Baillieul, F., Profizi, C., and Dupont, J. 2016. Spatial and temporal variation of cultivable communities of co-occurring endophytes and pathogens in wheat. Front. Microbiol. 7:403.

Cook, R. J., Boosalis, M. G., and Doupnik, B. 1978. Influence of crop residues on plant diseases. Publication 31, Pages 147-163 in: Crop Residue Management Systems. American Society of Agronomy, Crop Science Society of America, and Soil Science Society of America, Madison, WI.

Cookson, W. R., Beare, M. H., and Wilson, P. E. 1998. Effects of prior crop residue management on microbial properties and crop residue decomposition. Appl. Soil Ecol. 7:179-188.

Cordero, P., Príncipe, A., Jofré, E., Mori, G., and Fischer, S. 2014. Inhibition of the phytopathogenic fungus Fusarium proliferatum by volatile compounds produced by Pseudomonas. Arch. Microbiol. 196:803-809.

de Boer, W., Folman, L. B., Summerbell, R. C., and Boddy, L. 2005. Living in a fungal world: Impact of fungi on soil bacterial niche development. FEMS Microbiol. Rev. 29:795-811.

de Freitas, P. L., and Landers, J. N. 2014. The transformation of agriculture in Brazil through development and adoption of zero tillage conservation agriculture. Int. Soil Water Conserv. Res. 2:35-46.

De Silva, N. I., Brooks, S., Lumyong, S., and Hyde, K. D. 2019. Use of endophytes as biocontrol agents. Fungal Biol. Rev. 33:133-148.

Derpsch, R., Friedrich, T., Kassam, A., and Hongwen, L. 2010. Current status of adoption of no-till farming in the world and some of its main benefits. Biol. Eng. 3:1-25.

Dill-Macky, R., and Jones, R. K. 2000. The effect of previous crop residues and tillage on Fusarium head blight of wheat. Plant Dis. 84:71-76.

Dinis, M. J., Bezerra, R. M. F., Nunes, F., Dias, A. A., Guedes, C. V., Ferreira, L. M. M., Cone, J. W., Marques, G. S. M., Barros, A. R. N., and Rodrigues, M. A. M. 2009. Modification of wheat straw lignin by solid state fermentation with white-rot fungi. Bioresour. Technol. 100:4829-4835.

Dugan, F. M., Lupien, S. L., Hernandez-Bello, M., Peever, T. L., and Chen, W. 2005. Fungi resident in chickpea debris and their suppression of growth and reproduction of Didymella rabiei under laboratory conditions. J. Phytopathol. 153:431-439.

Dyer, P. S., Nicholson, P., Lucas, J. A., and Peberdy, J. F. 1996. Tapesia acuformis as a causal agent of eyespot disease of cereals and evidence for a heterothallic mating system using molecular markers. Mycol. Res. 100: 1219-1226.

Filho, A. B., Inoue-Nagata, A. K., Bassanezi, R. B., Belasque, J., Amorim, L., Macedo, M. A., Barbosa, J. C., Willocquet, L., and Savary, S. 2016. The importance of primary inoculum and area-wide disease management to crop health and food security. Food Secur. 8:221-238.

Flaishman, M. A., Eyal, Z., Zilberstein, A., Voisard, C., and Haas, D. 1996. Suppression of Septoria tritici blotch and leaf rust of wheat by recombinant cyanide-producing strains of Pseudomonas putida. Mol. Plant-Microbe Interact. 9:642-645.

Foxman, B., and Rosenthal, M. 2013. Implications of the human microbiome project for epidemiology. Am. J. Epidemiol. 177:197-201.

Gaillard, V., Chenu, C., Recous, S., and Richard, G. 1999. Carbon, nitrogen and microbial gradients induced by plant residues decomposing in soil. Eur. J. Soil Sci. 50:567-578.

Gdanetz, K., and Trail, F. 2017. The wheat microbiome under four management strategies, and potential for endophytes in disease protection. Phytobiomes J. $1: 158-168$.

Gosende, S., Penaud, A., Aubertot, J. N., Schneider, O., and Pinochet, X. 2003. Evolution of soil surface oilseed rape stubbles and their ability to produce spores of Leptosphaeria maculans: Preliminary results. Pages 1166-1168 in: Proc. 11th Int. Rapeseed Congr., Copenhagen, Denmark. http://gcirc.org/ fileadmin/documents/Proceedings/IRC2003Copen/AGRO\%20diseases/ AP11.14.pdf

Govaerts, B., Mezzalama, M., Unno, Y., Sayre, K. D., Luna-Guido, M., Vanherck, K., Dendooven, L., and Deckers, J. 2007. Influence of tillage, residue management, and crop rotation on soil microbial biomass and catabolic diversity. Appl. Soil Ecol. 37:18-30.

Govaerts, B., Verhulst, N., Castellanos-Navarrete, A., Sayre, K. D., Dixon, J., and Dendooven, L. 2009. Conservation Agriculture and soil carbon sequestration: Between myth and farmer reality. Crit. Rev. Plant Sci. 28: 97-122.

Granzow, S., Kaiser, K., Wemheuer, B., Pfeiffer, B., Daniel, R., Vidal, S., and Wemheuer, F. 2017. The effects of cropping regimes on fungal and bacterial communities of wheat and faba bean in a greenhouse pot experiment differ between plant species and compartment. Front. Microbiol. 8:902.
Grudzinska-Sterno, M., Yuen, J., Stenlid, J., and Djurle, A. 2016. Fungal communities in organically grown winter wheat affected by plant organ and development stage. Eur. J. Plant Pathol. 146:401-417.

Guetsky, R., Shtienberg, D., Elad, Y., and Dinoor, A. 2001. Combining biocontrol agents to reduce the variability of biological control. Phytopathology 91:621-627.

Guo, L., Zheng, S., Cao, C., and Li, C. 2016. Tillage practices and strawreturning methods affect topsoil bacterial community and organic $\mathrm{C}$ under a rice-wheat cropping system in central China. Sci. Rep. 6:33155.

Guo, X. W., Fernando, W. G. D., and Entz, M. 2005. Effects of crop rotation and tillage on blackleg disease of canola. Can. J. Plant Pathol. 27:53-57.

Hadas, A., Kautsky, L., Goek, M., and Erman Kara, E. 2004. Rates of decomposition of plant residues and available nitrogen in soil, related to residue composition through simulation of carbon and nitrogen turnover. Soil Biol. Biochem. 36:255-266.

Haddaway, N. R., Hedlund, K., Jackson, L. E., Kätterer, T., Lugato, E., Thomsen, I. K., Jørgensen, H. B., and Isberg, P. E. 2016. How does tillage intensity affect soil organic carbon? A systematic review protocol. Environ. Evid. 5:1.

Hanson, B. M., and Weinstock, G. M. 2016. The importance of the microbiome in epidemiologic research. Ann. Epidemiol. 26:301-305.

Hartman, K., van der Heijden, M. G. A., Wittwer, R. A., Banerjee, S., Walser, J. C., and Schlaeppi, K. 2018. Cropping practices manipulate abundance patterns of root and soil microbiome members paving the way to smart farming. Microbiome 6:14.

Hellequin, E., Monard, C., Quaiser, A., Henriot, M., Klarzynski, O., and Binet, F. 2018. Specific recruitment of soil bacteria and fungi decomposers following a biostimulant application increased crop residues mineralization. PLoS One 13:e0209089.

Henriksen, T., and Breland, T. 2002. Carbon mineralization, fungal and bacterial growth, and enzyme activities as affected by contact between crop residues and soil. Biol. Fertil. Soils 35:41-48.

Herrera Paredes, S., Gao, T., Law, T. F., Finkel, O. M., Mucyn, T., Teixeira, P. J. P. L., Salas González, I., Feltcher, M. E., Powers, M. J., Shank, E. A., Jones, C. D., Jojic, V., Dangl, J. L., and Castrillo, G. 2018. Design of synthetic bacterial communities for predictable plant phenotypes. PLoS Biol. 16: e2003962.

Hershman, D. E., and Perkins, D. M. 1995. Etiology of canola blackleg in Kentucky and seasonal discharge patterns of Leptosphaeria maculans ascospores from infested canola stubble. Plant Dis. 79:1225.

Hobbs, P. R. 2007. Conservation agriculture: What is it and why is it important for future sustainable food production? J. Agric. Sci. 145:127.

Ingwersen, J., Poll, C., Streck, T., and Kandeler, E. 2008. Micro-scale modelling of carbon turnover driven by microbial succession at a biogeochemical interface. Soil Biol. Biochem. 40:864-878.

Jørgensen, L. N., and Olsen, L. V. 2007. Control of tan spot (Drechslera triticirepentis) using cultivar resistance, tillage methods and fungicides. Crop Prot. 26:1606-1616.

Karlsson, I., Friberg, H., Kolseth, A.-K., Steinberg, C., and Persson, P. 2017. Organic farming increases richness of fungal taxa in the wheat phyllosphere. Mol. Ecol. 26:3424-3436.

Kassam, A., Friedrich, T., and Derpsch, R. 2019. Global spread of Conservation Agriculture. Int. J. Env. Stud. 76:29-51.

Kassam, A., Friedrich, T., Derpsch, R., and Kienzle, J. 2015. Overview of the worldwide spread of conservation agriculture. Field Actions Sci. Rep. J. Field Actions 8.

Kerdraon, L., Balesdent, M.-H., Barret, M., Laval, V., and Suffert, F. 2019a. Crop residues in wheat-oilseed rape rotation system: A pivotal, shifting platform for microbial meetings. Microbiol. Ecol. 77:931-945.

Kerdraon, L., Barret, M., Laval, V., and Suffert, F. 2019b. Differential dynamics of microbial community networks help identify microorganisms interacting with residue-borne pathogens: The case of Zymoseptoria tritici in wheat. Microbiome 7:125.

Kertész, Á., and Madarász, B. 2014. Conservation agriculture in Europe. Int. Soil Water Conserv. Res. 2:91-96.

Kildea, S., Ransbotyn, V., Khan, M. R., Fagan, B., Leonard, G., Mullins, E., and Doohan, F. M. 2008. Bacillus megaterium shows potential for the biocontrol of Septoria tritici blotch of wheat. Biol. Control 47:37-45.

Kriaučiuniene, Z., Velička, R., and Raudonius, S. 2012. The influence of crop residues type on their decomposition rate in the soil: A litterbag study. Zemdirbyste 99:227-236.

Kuzyakov, Y., and Blagodatskaya, E. 2015. Microbial hotspots and hot moments in soil: Concept \& review. Soil Biol. Biochem. 83:184-199.

Lagier, J.-C., Khelaifia, S., Alou, M. T., Ndongo, S., Dione, N., Hugon, P., Caputo, A., Cadoret, F., Traore, S. I., Seck, E. H., et al. 2016. Culture of 
previously uncultured members of the human gut microbiota by culturomics. Nat. Microbiol. 1:16203.

Larran, S., Perelló, A., Simón, M. R., and Moreno, V. 2007. The endophytic fungi from wheat (Triticum aestivum L.). World J. Microbiol. Biotechnol. 23:565-572.

Larran, S., Simón, M. R., Moreno, M. V., Siurana, M. S., and Perelló, A. 2016. Endophytes from wheat as biocontrol agents against tan spot disease. Biol. Control 92:17-23.

Legrand, F., Picot, A., Cobo-Díaz, J. F., Chen, W., and Le Floch, G. 2017. Challenges facing the biological control strategies for the management of Fusarium head blight of cereals caused by $F$. graminearum. Biol. Control 113:26-38

Leplat, J., Friberg, H., Abid, M., and Steinberg, C. 2013. Survival of Fusarium graminearum, the causal agent of Fusarium head blight. A review. Agron. Sustain. Dev. 33:97-111.

Lô-Pelzer, E., Aubertot, J. N., David, O., Jeuffroy, M. H., and Bousset, L. 2009. Relationship between severity of blackleg (Leptosphaeria maculans/ L. biglobosa species complex) and subsequent primary inoculum production on oilseed rape stubble. Plant Pathol. 58:61-70.

Magid, J., de Neergaard, A., and Brandt, M. 2006. Heterogeneous distribution may substantially decrease initial decomposition, long-term microbial growth and $\mathrm{N}$-immobilization from high $\mathrm{C}$-to-N ratio resources. Eur. J. Soil Sci. 57: 517-529.

Marchesi, J. R., and Ravel, J. 2015. The vocabulary of microbiome research: A proposal. Microbiome 3:31.

Marcroft, S. J., Sprague, S. J., Pymer, S. J., Salisbury, P. A., and Howlett, B. J. 2003. Factors affecting production of inoculum of the blackleg fungus (Leptosphaeria maculans) in south-eastern Australia. Aust. J. Exp. Agric. 43: 1231-1236.

Marschner, P., Umar, S., and Baumann, K. 2011. The microbial community composition changes rapidly in the early stages of decomposition of wheat residue. Soil Biol. Biochem. 43:445-451.

Mehra, L. K., Cowger, C., Weisz, R., and Ojiambo, P. S. 2015. Quantifying the effects of wheat residue on severity of Stagonospora nodorum blotch and yield in winter wheat. Phytopathology 105:1417-1426.

Morais, D., Gélisse, S., Laval, V., Sache, I., and Suffert, F. 2016. Inferring the origin of primary inoculum of Zymoseptoria tritici from differential adaptation of resident and immigrant populations to wheat cultivars. Eur. J. Plant Pathol. 145:393-404.

Navarro-Noya, Y. E., Gomez-Acata, S., Montoya-Ciriaco, N., Rojas-Valdez, A., Suarez Arriaga, M. C., Valenzuela-Encinas, C., Jimenez-Bueno, N., Verhulst, N., Govaerts, B., and Dendooven, L. 2013. Relative impacts of tillage, residue management and crop rotation on soil bacterial communities in a semi-arid agroecosytem. Soil Biol. Biochem. 65:86-95.

Nicolardot, B., Bouziri, L., Bastian, F., and Ranjard, L. 2007. A microcosm experiment to evaluate the influence of location and quality of plant residues on residue decomposition and genetic structure of soil microbial communities. Soil Biol. Biochem. 39:1631-1644.

Pascault, N., Cécillon, L., Mathieu, O., Hénault, C., Sarr, A., Lévêque, J., Farcy, P., Ranjard, L., and Maron, P.-A. 2010b. In situ dynamics of microbial communities during decomposition of wheat, rape, and alfalfa residues. Microbiol. Ecol. 60:816-828.

Pascault, N., Nicolardot, B., Bastian, F., Thiébeau, P., Ranjard, L., and Maron, P.-A. 2010a. In situ dynamics and spatial heterogeneity of soil bacterial communities under different crop residue management. Microbiol. Ecol. 60: 291-303.

Pascault, N., Ranjard, L., Kaisermann, A., Bachar, D., Christen, R., Terrat, S., Mathieu, O., Lévêque, J., Mougel, C., Henault, C., Lemanceau, P., Péan, M., Boiry, S., Fontaine, S., and Maron, P. A. 2013. Stimulation of different functional groups of bacteria by various plant residues as a driver of soil priming effect. Ecosystems (N.Y.) 16:810-822.

Paulitz, T. C., and Matta, A. 1999. The role of the host in biological control of diseases. Pages 394-410 in: Integrated Pest and Disease Management in Greenhouse Crops. Developments in Plant Pathology. Vol. 14. R. Albajes, L.-M. Gullino, J. C. van Lenteren, and Y. Elad, eds. Springer, Dordrecht.

Peñuelas, J. L., Rico, L., Ogaya, R., Jump, A. S., and Terradas, J. 2012. Summer season and long-term drought increase the richness of bacteria and fungi in the foliar phyllosphere of Quercus ilex in a mixed Mediterranean forest. Plant Biol. 14:565-575.

Perello, A., Simon, M. R., and Arambarri, A. M. 2002. Interactions between foliar pathogens and the saprophytic microflora of the wheat (Triticum aestivum L.) phylloplane. J. Phytopathol. 150:232-243.

Pereyra, S. A., and Dill-Macky, R. 2008. Colonization of the residues of diverse plant species by Gibberella zeae and their contribution to Fusarium head blight inoculum. Plant Dis. 92:800-807.
Pereyra, S. A., Dill-Macky, R., and Sims, A. L. 2004. Survival and inoculum production of Gibberella zeae in wheat residue. Plant Dis. 88:724-730.

Perez, C., Dill-Macky, R., and Kinkel, L. L. 2008. Management of soil microbial communities to enhance populations of Fusarium graminearum-antagonists in soil. Plant Soil 302:53-69.

Pfender, W. F., Zhang, W., and Nus, A. 1993. Biological control to reduce inoculum of the tan spot pathogen Pyrenophora tritici-repentis in surfaceborne residues of wheat fields. Phytopathology 83:371-375.

Pimentel, D., Harvey, C., Resosudarmo, P., Sinclair, K., Kurz, D., McNair, M., Crist, S., Shpritz, L., Fitton, L., Saffouri, R., et al. 1995. Environmental and economic costs of soil erosion and conservation benefits. Science 267:1117-1123.

Poll, C., Marhan, S., Ingwersen, J., and Kandeler, E. 2008. Dynamics of litter carbon turnover and microbial abundance in a rye detritusphere. Soil Biol. Biochem. 40:1306-1321.

Ramarathnam, R., and Dilantha Fernando, W. 2006. Preliminary phenotypic and molecular screening for potential bacterial biocontrol agents of Leptosphaeria maculans, the blackleg pathogen of canola. Biocontrol Sci. Technol. 16: 567-582.

Reicosky, D. C., and Allmaras, R. R. 2003. Advances in tillage research in North American cropping systems. J. Crop Prod. 8:75-125.

Ritpitakphong, U., Falquet, L., Vimoltust, A., Berger, A., Métraux, J.-P., and L'Haridon, F. 2016. The microbiome of the leaf surface of Arabidopsis protects against a fungal pathogen. New Phytol. 210:1033-1043.

Sapkota, R., Knorr, K., Jørgensen, L. N., O'Hanlon, K. A., and Nicolaisen, M. 2015. Host genotype is an important determinant of the cereal phyllosphere mycobiome. New Phytol. 207:1134-1144.

Sengeløv, G., Kowalchuk, G. A., and Sørensen, S. J. 2000. Influence of fungal-bacterial interactions on bacterial conjugation in the residue sphere. FEMS Microbiol. Ecol. 31:39-45.

Sergaki, C., Lagunas, B., Lidbury, I., Gifford, M. L., and Schäfer, P. 2018. Challenges and approaches in microbiome research: From fundamental to applied. Front. Plant Sci. 9:1205.

Shahbaz, M., Kuzyakov, Y., Sanaullah, M., Heitkamp, F., Zelenev, V., Kumar, A., and Blagodatskaya, E. 2017. Microbial decomposition of soil organic matter is mediated by quality and quantity of crop residues: Mechanisms and thresholds. Biol. Fertil. Soils 53:287-301.

Shaw, M. W., and Royle, D. J. 1989. Airborne inoculum as a major source of Septoria tritici (Mycosphaerella graminicola) infections in winter wheat crops in the UK. Plant Pathol. 38:35-43.

Smil, V. 1999. Crop residues: Agriculture's largest harvest: Crop residues incorporate more than half of the world's agricultural phytomass. Bioscience 49:299-308.

Stone, B. W. G., Weingarten, E. A., and Jackson, C. R. 2018. The role of the phyllosphere microbiome in plant health and function. Annu. Plant Rev. 1: $1-24$.

Suffert, F., Delestre, G., and Gélisse, S. 2018. Sexual reproduction in the fungal foliar pathogen Zymoseptoria tritici is driven by antagonistic densitydependence mechanisms. Microbiol. Ecol. 77:110-123.

Suffert, F., and Sache, I. 2011. Relative importance of different types of inoculum to the establishment of Mycosphaerella graminicola in wheat crops in north-west Europe: Wheat debris as local source of M. graminicola inoculum. Plant Pathol. 60:878-889.

Summerell, B. A., and Burgess, L. W. 1989. Factors influencing survival of Pyrenophora tritici-repentis: Stubble management. Mycol. Res. 93:38-40.

Tardy, V., Chabbi, A., Charrier, X., de Berranger, C., Reignier, T., Dequiedt, S., Faivre-Primot, C., Terrat, S., Ranjard, L., and Maron, P. A. 2015. Land use history shifts in situ fungal and bacterial successions following wheat straw input into the soil. PLoS ONE 10:e0130672.

Thompson, S., Tan, Y., Shivas, R., Neate, S., Morin, L., Bissett, A., and Aitken, E. 2015. Green and brown bridges between weeds and crops reveal novel Diaporthe species in Australia. Persoonia Mol. Phylogeny Evol. Fungi 35: 39-49.

Toju, H., Peay, K. G., Yamamichi, M., Narisawa, K., Hiruma, K., Naito, K., Fukuda, S., Ushio, M., Nakaoka, S., Onoda, Y., et al. 2018. Core microbiomes for sustainable agroecosystems. Nat. Plants 4:247-257.

Tsolakidou, M. D., Stringlis, I. A., Fanega-Sleziak, N., Papageorgiou, S., Tsalakou, A., and Pantelides, I. S. 2019. Rhizosphere-enriched microbes as a pool to design synthetic communities for reproducible beneficial outputs. FEMS Microbiol. Ecol. 95:fiz138.

Varsa, E. C., Chong, S. K., Abolaji, J. O., Farquhar, D. A., and Olsen, F. J. 1997. Effect of deep tillage on soil physical characteristics and corn (Zea mays L.) root growth and production. Soil Tillage Res. 43:219-228.

Vayssier-Taussat, M., Albina, E., Citti, C., Cosson, J.-F., Jacques, M.-A., Lebrun, M.-H., Le Loir, Y., Ogliastro, M., Petit, M.-A., Roumagnac, P., et al. 
2014. Shifting the paradigm from pathogens to pathobiome: New concepts in the light of meta-omics. Front. Cell. Infect. Microbiol. 4:29.

Verhulst, N., Govaerts, B., Verachtert, E., Castellanos-Navarrete, A., Mezzalama, M., Wall, P., Deckers, J., and Sayre, K. D. 2010. Conservation agriculture, improving soil quality for sustainable production systems? Pages 137-208 in: Food Security and Soil Quality. CRC Press, Boca Raton, FL.

Vera, D., and Murray, T. D. 2016. Occurrence and survival of apothecia of the eyespot pathogens Oculimacula acuformis and $O$. yallundae on wheat stubble in the U.S. Pacific Northwest. Plant Dis. 100:991-995.

Vorholt, J. A. 2012. Microbial life in the phyllosphere. Nat. Rev. Microbiol. 10: 828-840.

Wagner, M. R., Lundberg, D. S., Tijana, G., Tringe, S. G., Dangl, J. L., and Mitchell-Olds, T. 2016. Host genotype and age shape the leaf and root microbiomes of a wild perennial plant. Nat. Commun. 7:12151.

Wardle, D. A., Bardgett, R. D., Klironomosw, J. N., Setala, H., van der Putten, W. H., and Wall, D. H. 2004. Ecological linkages between aboveground and belowground biota. Science 304:1629-1633.

Wiggins, E. 2003. Green manures and cropping sequences influence indigenous soil-borne antagonists and plant disease. MsC Thesis, University of Minnesota, St. Paul, MN.
Wolfarth, F., Schrader, S., Oldenburg, E., and Brunotte, J. 2016. Mycotoxin contamination and its regulation by the earthworm species Lumbricus terrestris in presence of other soil fauna in an agroecosystem. Plant Soil 402: 331-342.

Wolfarth, F., Schrader, S., Oldenburg, E., and Weinert, J. 2013.

Nematode-collembolan-interaction promotes the degradation of Fusarium biomass and deoxynivalenol according to soil texture. Soil Biol. Biochem. 57: 903-910.

Wolfarth, F., Schrader, S., Oldenburg, E., Weinert, J., and Brunotte, J. 2011. Earthworms promote the reduction of Fusarium biomass and deoxynivalenol content in wheat straw under field conditions. Soil Biol. Biochem. 43: 1858-1865.

Xia, X., Zhang, P., He, L., Gao, X., Li, W., Zhou, Y., Li, Z., Li, H., and Yang, L. 2019. Effects of tillage managements and maize straw returning on soil microbiome using 16S rDNA sequencing. J. Integr. Plant Biol. 61: 765-777.

Zhang, X., Zhang, R., Gao, J., Wang, X., Fan, F., Ma, X., Yin, H., Zhang, C., Feng, K., and De, Y. 2017. Thirty-one years of rice-rice-green manure rotations shape the rhizosphere microbial community and enrich beneficial bacteria. Soil Biol. Biochem. 104:208-217. 